\title{
1 Species-specific impact of microplastics on coral physiology
}

${ }^{* 1}$ Mendrik, F. M., ${ }^{2}$ Henry, T.B, ${ }^{2,3}$ Burdett, H., ${ }^{4}$ Hackney,C.R. , ${ }^{5}$ Waller, C, ${ }^{6}$ Parsons, D.

R. ${ }^{7}$ Hennige S.J.

${ }^{1}$ School of GeoSciences, University of Edinburgh, Edinburgh, EH93FE, UK, present address: University of Hull, Energy and Environment Institute, Cottingham Road,

Hull, East Riding, HU6 7RX, UK

2School of Energy, Geoscience, Infrastructure and Society, Heriot-Watt University, Edinburgh, EH14 4AS

${ }^{3}$ Lyell Centre for Earth and Marine Science and Technology, Edinburgh, EH14 4BA

${ }^{4}$ Geography, Politics and Sociology, Newcastle University, Newcastle upon Tyne, UK.

${ }^{5}$ Department of Biology and Marine Sciences, School of Science and Engineering,

University of Hull, Cottingham Road, Hull, East Riding, HU6 7RX, UK

${ }^{6}$ Energy and Environment Institute, University of Hull, Cottingham Road, Hull, East Riding, HU6 7RX, UK

${ }^{7}$ School of GeoSciences, University of Edinburgh, Edinburgh, EH93FE, UK

*Corresponding author: f.mendrik-2018@hull.ac.uk,

\section{Highlights}

- 2 species of corals were exposed to_2 different polymers and shapes (spheres and fibres) of microplastic typess at ambient and elevated temperatures

- We assessed effects of microplastics on-gross photosynthesis, net respiration, and photosynthetic yields of photosystem Ilwere assessed

- Responses were species, microplastic type, and temperature-dependent and microplastic-specific

- Fibres decreased microplastic fibres caused a $41 \%$ reduction in photosynthetic ability_at ambient temperature over 12 days-for Acropora sp.

- No stress response occurred at elevated temperature for either species.

\section{Abstract}

There is evidence that microplastic (MP) pollution can negatively influence coral health; however, mechanisms are unknown and most studies have used MP exposure concentrations that are considerably higher than current environmental conditions. Furthermore, whether MP exposure influences coral susceptibility to 
other stressors such as ocean warming is unknown. Our objective was to determine the physiology response of corals exposed to MP concentrations that have been observed in-situ at ambient and elevated temperature that replicates ocean warming. Here, two sets of short-term experiments were conducted at ambient and elevated temperature, exposing the corals Acropora sp. and Seriatopora hystrix to microspheres and microfibres. Throughout the experiments, gross photosynthesis and net respiration was quantified using a 4-chamber coral respirometer, and photosynthetic yields of photosystem II were measured using Pulse-Amplitude Modulated (PAM) fluorometry. Results indicate the effect of MP exposure is dependent on MP type, coral species, and temperature.

MP fibres (but not spheres) reduced photosynthetic capability of Acropora sp., with a $41 \%$ decrease in photochemical efficiency at ambient temperature over 12 days. No additional stress response was observed at elevated temperature; photosynthetic performance significantly increased in Seriatopora hystrix exposed to MP spheres. These findings show that a disruption to coral photosynthetic ability can occur at MP concentrations that have been observed in the marine environment and that MP pollution impact on corals remains an important aspect for further research.

\section{Graphical abstract}

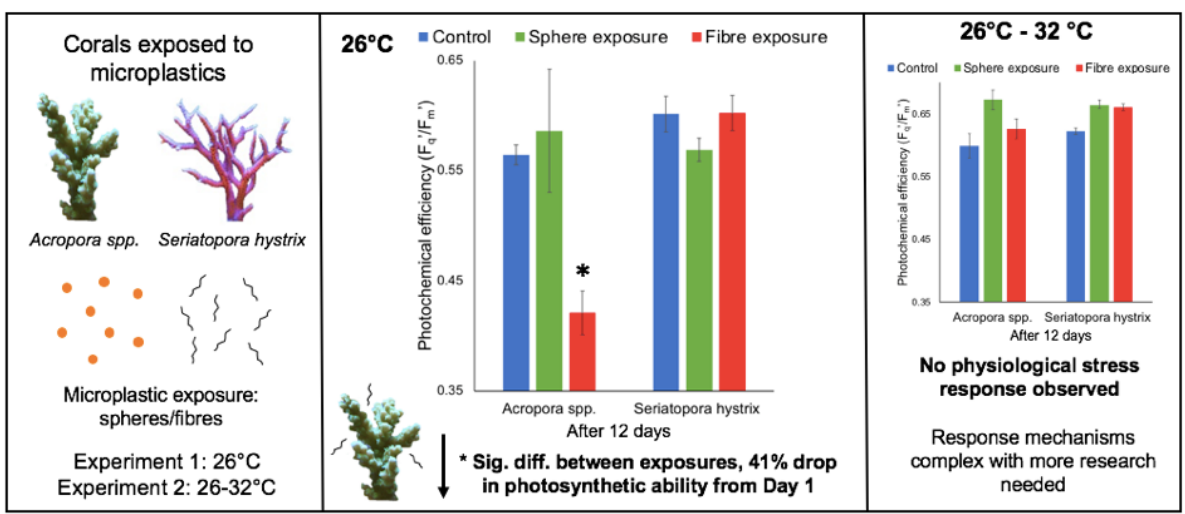

Keywords: Microplastic; Reef-building corals; Ocean warming; Photosynthesis; Stress; Respiration

\section{Main finding summary:}

Photosynthetic ability of Acropora sp. exposed to microfibres was significantly lower compared to Seriatopora hystrix with a $41 \%$ decrease at ambient temperature. No stress response occurred at elevated temperature.

\section{Introduction}


Plastic is durable, lightweight and inexpensive to produce, becoming a favourable every-day material and causing the "age of plastics", with production increasing from 0.5 million tonnes/yr in 1960 to 348 million tonnes/yr in 2017_(Avio et al., 2017; PlasticsEurope (Association of Plastics Manufacturers), 2018). These properties have ensured plastic waste has developed into a serious threat to the marine environment_(Derraik, 2002; Ryan et al., 2009). An estimated $60-80 \%$ of the world's litter is plastic and approximately $10 \%$ of annual plastic production enters the sea from land-based sources that includes rivers, wastewater discharges and storm water runoff_(Derraik, 2002; Ryan et al., 2009). Marine plastic pollution is having detrimental repercussions on the marine environment, contaminating ecosystems and reaching the world's most remote locations, such as Antarctica_(Cincinelli et al., 2017; Munari et al., 2017; Ryan et al., 2009; Walker, 2018). Impacts include entanglement and death of marine wildlife, loss of aesthetic value and an increase in economic costs for remediation_(Avio et al., 2017; Derraik, 2002). It is well known that larger pieces of plastics are a threat to marine life, although there is still relatively little information on the impact of MPs on marine ecosystems such as coral reefs_(Chae and An, 2017; Derraik, 2002; Halden, 2010; Meeker et al., 2009; PlasticsEurope (Association of Plastics Manufacturers), 2018).

Microplastics (MPs), plastic fragments defined as $<5 \mathrm{~mm}$, are more difficult to manage than macroplastics due to their size and are of high environmental concern (Avio et al., 2015; Cincinelli et al., 2017; Wright et al., 2013). MPs have been found within numerous organisms and can elicit substantial impacts such as reducing feeding, immunity and survival within laboratory exposure studies (Lusher et al., 2013; Murray and Cowie, 2011; Provencher et al., 2014; Setälä et al., 2014; Sussarellu et al., 2016). While exposure and ingestion of MPs occurs in numerous marine organisms, the implications of this exposure at levels that have been observed in situ on overall health and survival are unknown_(Fossi et al., 2012; Wright et al., 2013). Several laboratory studies suggest that leaching of constituent contaminants including plastic additives and monomers from MPs are capable of causing endocrine disruption and bioaccumulation_(Oehlmann et al., 2008; Talsness, 2009)._However, there is no evidence of endocrine disruption from substances sorbed to MPs at environmentally relevant concentrations.

The small size of MPs is one of the main factors contributing to their accessibility to lower trophic organisms_(Arossa et al., 2019; Browne et al., 2008; Garnier et al., 2019; Lusher et al., 2013; Setälä et al., 2014). Plastic pollution origin is mainly terrestrial and therefore coastal ecosystems such as coral reefs are particularly at risk_(Reichert et al., 2018). Impacts of MPs to coral reefs is of increasing concern because of their high biodiversity and significant economic value (Hamilton et al., 2017; Richmond, 1993). A key concern is that impacts of climate change-related warming may be accentuated by pollutants such as MP exposure (Hughes et al., 2017). Exposure of corals to MPs may happen in numerous ways, especially at low tide when floating plastic can come into contact with corals on shallow reefs_(Hall et al., 2015). Previous studies have shown that corals are non- 
selective feeders, with common scleractinian corals ingesting a range of food from bacteria to mesozooplankton within a size range of $0.2-1,000 \mu \mathrm{m}$ and a preference for smaller particles_(Anthony, 1999; Hall et al., 2015; Mills et al., 2004). As MPs are within the size range that corals ingest, and there is evidence that corals do ingest MPs (Allen et al., 2017; Hall et al., 2015; Hankins et al., 2018; Reichert et al., 2018), investigation of the effects of MP exposure in corals is a priority.

MPs (at high concentration) can disturb the initiation of symbiotic relationships in certain coral species which plays an important role in coral ability to adapt to environmental change_(Okubo et al., 2018). Therefore, as MP pollution continues to rise, coral exposure to MPs may reach high levels in the future, potentially reducing coral resilience to environmental change and making reefs more vulnerable (LaJeunesse et al., 2018; Okubo et al., 2018). There is little literature on the responses and defence mechanisms of marine organisms when ingesting MPs, but studies have investigated the production of reactive oxygen species (ROS) and enzymes including superoxide dismutase (SOD) due to MP exposure. Evidence from organisms (photosynthetic and non-photosynthetic) indicate that the overproduction of ROS is significant after MP exposure and can cause oxidative damage (Bhattacharya et al., 2010; Chen et al., 2017; Paul-Pont et al., 2016). In the case of the coral holobiont, this could lead to decreased photosynthetic efficiencies and a breakdown in the host-symbiont relationship, exacerbating coral bleaching responses.

Recently, MPs have been identified to compromise coral health, by reducing growth and altering photosynthetic performance (especially maximum photochemical efficiency), with species-specific responses observed_(Reichert et al., 2019). However this was observed at a MP concentration of 200 particles $L^{-1}$ which does not represent current environmental levels, similar to many lab-based exposure studies. For example, several investigations into MP concentration on coral reefs (including in the South China Sea, Great Barrier Reef and the Maldives) found a range of 0-45 MP items $\mathrm{L}^{-1}$ in situ (Ding et al., 2019; Huang et al., 2019; Nie et al., 2019; Saliu et al., 2018); yet previous studies have tended to use concentrations two to seven orders-of-magnitude higher than environmental quantities_(Lenz et al., 2016). Here, we explore whether MP exposure, at environmentally relevant concentrations, will cause a reduction in coral physiology or photosynthetic efficiencies, and whether this is exacerbated by thermal perturbation.

\section{Materials and Methods}

Two twelve-day experiments were conducted at the University of Edinburgh, to study the impact of two different types MPs (see section 2.1) on the photosynthetic capability and respiration of two species of coral (Acropora sp. and Seriatopora hystrix) at ambient and elevated temperatures. The first experiment exposed fragments of Acropora sp. and Seriatopora hystrix to MPs at ambient temperature, $26^{\circ} \mathrm{C}$. The second set of experiments used new fragments and the same setup at 
ambient temperature $\left(26^{\circ} \mathrm{C}\right)$ after the tanks had full water changes and had been cleaned, with the temperature elevating from $26^{\circ} \mathrm{C}$ to $32^{\circ} \mathrm{C}$ by $0.5^{\circ} \mathrm{C}$ every two days. Both experiments also had control set-ups where coral fragments were not exposed to MP but to ambient and elevating temperatures.

\subsection{Preliminary set-up}

i) Preparation of corals

Corals of the genus Acropora and Seriatopora hystrix were used for this investigation. Acropora sp. is an important dominant reef-building genus and one of the most abundant and species-rich groups of corals in the world. Acropora sp. is typically sensitive to anthropogenic ecosystem change_(Greer et al., 2009) S.hystrix is a branching coral, widely distributed in the Indo-Pacific and thought to be more resilient to environmental change_(Anderson, 2014). Corals raised in aquaria were provided by the Tropical Marine Centre, Manchester, UK and were cut using clippers into 110 fragments $\sim 30 \mathrm{~mm}$ long per species. Fragments were glued to coral plugs and acclimatised to tank conditions at $26^{\circ} \mathrm{C}$ for at least 14 days.

\section{ii) Microplastics}

Polystyrene is one of the most used plastics globally, typically seen in packaging and was chosen as it is a commonly found plastic polymer in MP sampling at sea and beaches_(Barnes et al., 2009; Browne et al., 2010). Fibres are also one of the most found marine MP types, with an important source originating through sewage contaminated by fibres from washing clothes_(Browne et al., 2011; Claessens et al., 2011). Polystyrene spheres produced for the NERC RealRiskNano Project (size range 500-1000 $\mu \mathrm{m}, \mathrm{MP1}$ ), as described by Al-Sid-Cheikh et al.,_2018)_and microfibres (size range $0.05-1 \mathrm{~cm}, \mathrm{MP} 2$ ) extracted from tumble dryer lint were used for experimentation. $50 \mathrm{ml}$ stock solutions were made of each respective MP with artificial seawater (Tropic Marin) in $100 \mathrm{ml}$ beakers, wrapped in aluminium foil and kept in a fridge to prevent biofilm growth and degradation of MPs. Stocks were mixed by magnetic stirrers for 10 minutes before being added to tanks. As extrapolated by Lenz et al. (2016), MP concentration in various marine environments ranges from approximately $1 \mu \mathrm{g} / \mathrm{L}-1 \mathrm{ng} / \mathrm{L}$. However, previous MP concentrations for coral studies range from $2.5-395 \mathrm{mg} / \mathrm{L}$. Therefore, stocks were added to experimental flasks to a final concentration of $0.1 \mathrm{mg} / \mathrm{L}$ as a more environmentally relevant concentration but also to be comparable to previous coral exposure studies (Lenz et al., 2016).

\subsection{Tank set-up, water chemistry and microplastic treatments}

Four tanks were utilised with each experiment being a closed system to prevent contamination. Each tank had one heater, circulation pump and lights with a 12:12 photoperiod, PAR 50 $\mu$ mols. Salinity was maintained at 36 ppt. An Orion Star A211 $\mathrm{pH}$ meter was used with Orion 8302BNUMD ROSS Ultra pH/ATC Triode to monitor 
$\mathrm{pH}$ daily. Five replicate fragments of each genus were placed into each tank which had different treatments: two control (CTR) tanks, one polystyrene sphere (MP1) treatment and one MP fibre (MP2) treatment. This was repeated at elevated temperature conditions.

\subsection{Non-invasive assessment of coral health}

Chlorophyll a fluorescence is a rapid and non-invasive technique for assessing the photosynthetic apparatus status of coral Symbiodinaceae and any effects of contaminants that may inhibit Photosystem (PS) II electron transport_(Elahifard et al., 2013; Jones et al., 2000; Schreiber, 2004), with many studies using Pulse-Amplitude Modulated (PAM) fluorometry in coral research (Jones et al., 2000, 1998; Jones and Hoegh-Guldberg, 2001; Owen et al., 2003; Ralph et al., 2001; Schreiber, 2004; Warner et al., 1996). PAM fluorometry has also been utilised to determine whether a compound, such as MPs, have phytotoxic interactions (additive, synergistic or antagonistic) with species_(Elahifard et al., 2013; Franqueira et al., 2000).

$\mathrm{F}_{\mathrm{q}}{ }^{\prime} / \mathrm{F}_{\mathrm{m}}{ }^{\prime}$ is correlated with the quantum yield of photochemistry in PSII and reflects the probability that the PSII reaction centres will utilise the available excitation energy for photochemisty_(Jones et al., 2000). Photoinhibition of photosynthesis is synonymous with changes in chlorophyll fluorescence characteristics, including a decrease of photosynthetic electron transport activity and a loss of quantum yield_(Jones and Hoegh-Guldberg, 2001). $\mathrm{F}_{\mathrm{q}}{ }^{\prime} / \mathrm{Fm}_{\mathrm{m}}$ ' was the chosen chlorophyll a parameter for this study as it has been used throughout literature as a reliable method to measure photochemical efficiency (Brack and Frank, 1998; Krause and Weis, 1991; Schreiber et al., 1993). A Diving-PAM MK2 fluorometer (Walz) was used for all measurements. Chlorophyll a fluorescence was stimulated by a pulse modulated red LED at $650 \mathrm{~nm}$, and corals were quasi-dark adapted_(Hennige et al., 2008) before saturation pulse measurements $\left(\mathrm{Y}_{(\mathrm{II})}\right)$ were taken each day to quantify fluorescence yield ( $\mathrm{F}_{\mathrm{m}}$ ' and $\mathrm{F}^{\prime}$ ) and derive $F_{q^{\prime}} / F_{m}{ }^{\prime}$ (Table 1) (Hennige et al., 2008). It should be noted that when collecting $\mathrm{F}_{\mathrm{q}}{ }^{\prime} / \mathrm{F}_{\mathrm{m}}{ }^{\prime}$ data using a PAM fluorometer, different areas of the coral were sampled each day, which may have caused some additional variation. In addition, weekly rapid light curves were conducted on each coral fragment to determine the relative Electron Transport Rate (rETR) (Genty et al., 1989). Maximum rETR was compared between variables within experiments. Measurement definitions and their abbreviations are summarised in Table 1.

\subsection{Respirometry}

A 4-chamber coral respirometer was used at the beginning and end of each experiment to quantify gross photosynthesis and net respiration (Hennige et al., 2008; Lesser, 1997; Levy et al., 2006; Mass et al., 2007). Fragments were placed in $230 \mathrm{ml}$ incubation chambers each fitted with oxygen optodes (Presens) and connected to a temperature-compensated oxygen analyser. Corals were acclimated 
in the respirometer for 30 minutes with measurements in light and dark conditions running for 30 minutes each. Respirometry analysis was undertaken at day 1 and 12 of each experiment.

\subsection{Statistical analysis}

The combined effects of interactions between treatment (control, MP1 and MP2) and temperature (ambient and elevated), and treatment and species on $\mathrm{F}_{\mathrm{q}}{ }^{\prime} / \mathrm{F}_{\mathrm{m}}$ ', gross photosynthesis and net respiration were assessed using two-way analysis of variance (ANOVA), followed by Tukey's HSD post hoc test. Analysis of data collected at the end of the 12-day experiments was conducted. Where necessary, data was transformed using arcsine of square root (proportion data) or inverse transformation to conform to the parametric test assumptions. Before the parametric analysis, Shapiro-Wilk and Levene tests were applied to assess the normality and homogeneity of variance, respectively, of data distribution. Parametric assumptions were met for all analysis. Two-way ANOVAs were considered statistically significant if $p \leq 0.05$. All statistical analysis was conducted using $R$ ( $R$ Core Team, 2013).

\section{Results}

The presence microplastics significantly affected the physiology of corals depending on species and temperature interactions. The specific results are presented in the following subtopics.

\subsection{Species specific impacts of microplastics to coral (photo)physiology}

There was a statistically significant interaction between the effects of species and treatment on $\mathrm{F}_{\mathrm{q}}^{\prime} / \mathrm{F}_{\mathrm{m}}$ ' at the end of the 12 day experiment (ANOVA,

$\mathrm{F}(2,62)=5.925, \mathrm{p}=0.004)$ as shown in Fig. $1 \mathrm{~A}-\mathrm{D})$. In particular, $\mathrm{F}_{\mathrm{q}}{ }^{\prime} / \mathrm{F}_{\mathrm{m}}$ ' of corals exposed to fibres (MP2) was significantly lower for Acropora sp. compared to S.hystrix (Tukey's multiple comparison test, $\mathrm{p}=0.008$ ). For Acropora sp. exposed to spheres (MP1), Fq'/Fm' was significantly higher compared to controls (Tukey's multiple comparison test, $\mathrm{p}=0.040$ ) and fibres (MP2) (Tukey's multiple comparison test, $\mathrm{p}=0.001$ ).

There was a statistically significant interaction between the effects of species and treatment on gross photosynthesis (ANOVA, $F(2,45)=7.091, p=0.002$ ), (Fig. 2 A- 
280

281

282

D). For S.hystrix, gross photosynthesis was considerably higher for spheres (MP1) than fibres (MP2), with a significant difference between the effects of MP1 and MP2 (Tukey's multiple comparison test, $\mathrm{p}=0.027$ ) (Fig. $2 \mathrm{~B}$ and D)). Analysis of net respiration showed no statistically significant interactions or effects of treatments (ANOVA, $\mathrm{F}(2,56)=1.33, \mathrm{p}=0.273$ ) but a significant difference between species (ANOVA, $F(1,56)=7.37) p=0.009)$.

\subsection{Temperature specific impacts of microplastics to coral (photo)physiology}

There was a statistically significant interaction between the effects of temperature and treatment on $F_{q}{ }^{\prime} / F_{m}{ }^{\prime}(A N O V A, F(2,62)=4.320, p=0.018)$, (Fig. 1 A-D). A significantly higher $\mathrm{F}_{\mathrm{q}}^{\prime} / \mathrm{F}_{\mathrm{m}}$ ' was observed for corals exposed to spheres (MP1) at elevated temperature compared to ambient temperature (Tukey's multiple comparison test, $\mathrm{p}=0.006$ ). $\mathrm{F}_{\mathrm{q}} / \mathrm{F}_{\mathrm{m}}$ ' of corals exposed to fibres (MP2) was also significantly higher at elevated temperatures (Tukey's multiple comparison test. $\mathrm{p}<0.001)$. In addition, at elevated temperature, there was a significant difference between control and spheres (MP1) for both coral species (Tukey's multiple comparison test, $\mathrm{p}=0.080$ ) (Fig.1 $\mathrm{C}-\mathrm{D})$ ), with lower $\mathrm{F}_{\mathrm{q}}{ }^{\prime} / \mathrm{F}_{\mathrm{m}}$ ' observed for control corals.

Likewise, there was a statistically significant interaction between the effects of temperature and treatment on gross photosynthesis. (ANOVA,

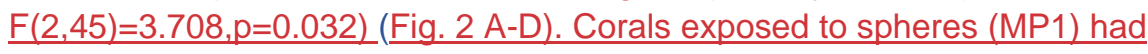
significantly higher gross photosynthesis at elevated temperature compared to ambient temperature (Tukey's multiple comparison test, $\mathrm{p}=0.034$ ), in addition to a significantly higher gross photosynthesis compared to corals exposed to fibres (MP2) ffibres (MP2) ( $\mathrm{p}=0.045)$ at elevated temperature (Tukey's multiple comparison test, Fig.2 C-D)). This is due to gross photosynthesis being particularly high for S.hystrix at elevated temperature (Fig.2 D).

\section{Discussion}

The short-term exposure to MPs tested here resulted in a species-specific and MPspecific stress response between two reef-building coral species.

$\underline{\mathrm{F}_{\mathrm{g}}{ }^{\prime} / \mathrm{F}_{\mathrm{m}}{ }^{\prime} \text { of }}$ corals exposed to MP fibres was significantly lower for Acropora sp. compared to S.hystrix, at ambient temperature, with a $41 \%$ decrease in $\mathrm{F}_{\mathrm{q}}{ }^{\prime} / \mathrm{F}_{\mathrm{m}}{ }^{\prime}$ for Acropora sp. over a 12 day period. However, Acropora sp. exposed to MP spheres showed significantly higher $\mathrm{F}^{\prime} / \mathrm{Fm}_{\mathrm{m}}$ ' compared to control and MP fibre treatments.

At elevated temperature, no negative physiological response was observed for either At elevated temperature, no negative 


\section{MP spheres.}

This study supports current literature that negative impacts of MPs are species This study supports current literature that negative impacts of MPs are species specific (Reichert et al., 2019, 2018), but importantly, also shows these results at concentrations that replicate environmental levels. $\underline{\text { Our results } \underline{\text { further }}}$ highlight the need for more investigations to fully understand observed physiological responses.

At ambient temperature, the significantly reduced photosynthetic efficiency of PSII $\left(F_{q}{ }^{\prime} / F_{m}{ }^{\prime}\right)$ for Acropora sp. may have occurred for several reasons. When photosynthetic efficiency $\left(\mathrm{F}_{\mathrm{q}}{ }^{\prime} / \mathrm{F}_{\mathrm{m}}{ }^{\prime}\right)$ is considered with the negative gross photosynthetic values observed ${ }_{2}$ it can be concluded that photosynthetic ability of Acropora sp. decreased when exposed to fibres. A decrease in the capacity of PSII may have been caused by the stress production of reactive oxygen species (ROS). This has been previously observed in Pocillopora damicornis, as well as the suppression of its detoxification and immune system when exposed to MPs_(Tang et al., 2018). An increase in ROS production either directly, or indirectly such as via organic radical formation, can result in heightened oxidative stress and biological damage due to limiting the fixation of $\mathrm{CO}_{2}$ and therefore inhibiting the repair of PSII (Bhattacharya et al., 2010; Livingstone, 2003; Takahashi and Murata, 2008). A difference in respiratory ability was also observed for Acropora sp., exposed to MPs having higher net respiration levels. Heightened respiratory activity is known to occur under stressful conditions in corals and anemones_(Edmunds, 2005; Leggat et al., 2011; Nii and Muscatine, 1997), supporting the hypothesis that interactions with MPs is energetically costly and may prevent normal coral functioning. These are speculations however and further study is necessary.

Coral exposure to microfibres can cause other stress responses that impair coral functioning further. Firstly, the interaction with microfibres may inhibit heterotrophic feeding. MPs have been observed to block normal food supply with continuous ingestion and egestion of MPs leading to little to no nutrients being obtained_(Chapron et al., 2018; Reichert et al., 2019). Fibres have been observed within the coral polyp, wrapped by mesenterial tissue causing extraction by the coral to be difficult_(Allen et al., 2017; Hall et al., 2015). In addition, MPs may become trapped in the mucus layer of corals and have the potential to trigger stress responses through further mucus production_(Hall et al., 2015; Reichert et al., 2018). These responses are all energetically costly, especially an increase in mucus production, which can use half of the carbon assimilated from photosynthesis_(Wild et al., 2004). As microfibres are thought to be the most abundant MP type in marine environments, it is likely that coral-microfibre interactions are already occurring, albeit at low levels_(Browne et al., 2011; Thompson et al., 2004; Wright et al., 2013). Fibres can also become entangled with other fibres, particles or tissue, making 
egestion even more demanding or impossible compared with other MP types such as spheres. Ingestion of MP fibres in particular can therefore cause blockages and feeding difficulties in addition to impeding normal digestion of natural food as mesenterial tissues are the primary tissue involved in digestion (Goldberg, 2002). The stress response observed for Acropora sp. at ambient temperature may have long-term effects including reduced growth, fecundity, ability to repair, and survival. Acropora sp. are typically a more sensitive species and form important frameworks for reefs. As MP pollution levels continue to rise, this may therefore threaten reef composition by reducing photosynthetic ability and growth of sensitive coral species.

The results observed here were species specific, with S.hystrix showing no change in physiology when exposed to MPs at ambient temperature, supporting previous studies at higher MP concentrations (Mouchi et al., 2019; Reichert et al., 2019). This may be due to differences in feeding capacity and behaviour, with Acropora interacting with MPs more_(Hall et al., 2015). Furthermore, MPs can disturb the anthozoan-algae symbiotic relationship in both coral and anemones, supressing the uptake of Symbiodinaceae_(Okubo et al., 2018). The symbiotic alga-coral relationship may have been disturbed in Acropora sp., with the host producing stress responses that impacts downstream on the Symbiodinaceae, reducing photosynthetic capability_(Okubo et al., 2018). Symbiodinaceae differ in sensitivity and therefore some species may be more sensitive to MP disturbance. Acropora sp. are typically more sensitive to environmental change compared to other corals. This may explain the species-specific responses observed ${ }_{2}$ but a wider range of species must be tested under long-term MP exposures at ambient temperatures.

It was expected that elevated temperatures would accentuate the negative physiological impacts of MP exposure on corals_(Biscéré et al., 2017), yet this was not observed. Acropora sp. showed no change in photosynthetic or respiratory ability, yet $S$.hystrix had considerably higher photosynthetic ability $\left(F_{q}{ }^{\prime} / F_{m}{ }^{\prime}\right.$ and gross photosynthesis) when exposed to either type of MP. MPs may destabilise the functioning of the symbiotic alga-host relationship by inducing the production of ROS (Dubinsky and Stambler, 1996; Okubo et al., 2018). However, acclimation to thermal stress can occur through production of oxidative enzymes to inactive damaging oxygen radicals or heat shock proteins that refold denatured cellular and structural proteins_(Coles and Brown, 2003; Hofmann and Todgham, 2010; Weis, 2010). A speculation for why these results were observed is that through these mechanisms (acclimation), the coral may become more resistant to the damage caused by MP exposure with temperature (within time scales of experiments here). At ambient temperature, the photosynthetic capability of Acropora sp. was lowered as a result of exposure to MP fibres which may have been caused by ROS production and/or damage to PSII. However, at elevated temperature, acclimation may not only protect the holobiont from thermal stress but also ROS induced damage from the presence and damage of MPs. Physiological changes to corals due to stress, where the host switches to a primarily heterotrophic nutrition has been previously observed during bleaching events_(Grottoli et al., 2006). If MP exposure was maintained in the longterm, physiological acclimation may_manifest as a shift towards more 
401 thermotolerant Symbiodinaceae_or change in the associated microbial community 402 (Ainsworth and Hoegh-Guldberg, 2009; Fine and Loya, 2002; Reshef et al., 2006), 403 highlighting an important focus for future research.

\section{Conclusions}

Ultimately, our findings support the general view that MP exposure induces a negative impacts on the coral holobiont's photophysiology, albeit with species and MP type specificity. In particular, photosynthetic capability of Acropora sp., a globally important reef-building genus, was compromised even at ambient temperature. This investigation contributes to our understanding of the physiological effects of MPs by carrying out experiments at more environmentally-relevant concentrations at both ambient and elevated temperatures. Explanations for the results observed highlight the complex response mechanisms of corals to MP exposure and show the need for more research in this area. Future studies at both ambient and elevated temperatures should take a holistic view, interrogating impacts on the coral host and associated symbionts and bacterial communities. In addition, to further investigate impact mechanisms, a range of microplastic concentrations are needed. Importantly, research is needed in situ to determine MP concentration on coral reefs to inform future exposure studies and assess the extent of potential MP stress for coral reef management.

\section{Figures and Tables}

Table 1: Abbreviations and their definitions relevant for PAM fluorometry measurements

\begin{tabular}{|c|c|}
\hline ABBREVIATION & DEFINITION \\
\hline PAR & Photosynthetically active radiation \\
\hline PSII & $\begin{array}{l}\text { Photosystem II is a specialised protein } \\
\text { complex that uses light energy to drive } \\
\text { the transfer of electrons from water, } \\
\text { resulting in the production of oxygen in } \\
\text { photosynthesis }\end{array}$ \\
\hline $\mathrm{F}^{\prime}$ & Fluorescence yield - under actinic light \\
\hline $\mathrm{Fm}_{\mathrm{m}}^{\prime}$ & $\begin{array}{l}\text { The maximum fluorescence yield - } \\
\text { under actinic light }\end{array}$ \\
\hline $\mathrm{F}_{\mathrm{q}}^{\prime}$ & Fluorescence quenched $\left(F_{m}{ }^{\prime}-F^{\prime}\right)$ \\
\hline $\mathrm{F}_{\mathrm{q}}^{\prime} / \mathrm{F}_{\mathrm{m}}{ }^{\prime}$ & $\begin{array}{l}\text { Effective photochemical efficiency of } \\
\text { PSIl photochemistry (or effective }\end{array}$ \\
\hline
\end{tabular}




\begin{tabular}{|c|c|}
\hline & $\begin{array}{l}\text { quantum yield) at any given actinic } \\
\text { irradiance, determined by }\left(F_{m}{ }^{\prime}-F^{\prime}\right) / F_{m}{ }^{\prime} \text {. }\end{array}$ \\
\hline Maximum relative ETR & $\begin{array}{l}\text { The approximation of the maximum } \\
\text { electron transport rate }(\mu \mathrm{mol} \text { electrons } \\
\left.\mathrm{m}^{-2} \mathrm{~s}^{-1}\right) \text { determined by }(\text { Genty et al., } \\
1989) \text { : } \\
\text { relative } E T R=\Phi_{\mathrm{PSII}} \times P A R \\
\text { where effective quantum yield } \Phi_{\mathrm{PSII}} \text { is } \\
\text { determined by (Genty et al., } 1989) \text { : } \\
\qquad \Phi_{\mathrm{PSII}}=\frac{\left[F_{m}^{\prime}-F\right]}{F_{m}^{\prime}} \\
\text { with } \mathrm{F} \text { being the minimum florescence } \\
\quad \text { for light-adapted samples }\end{array}$ \\
\hline
\end{tabular}



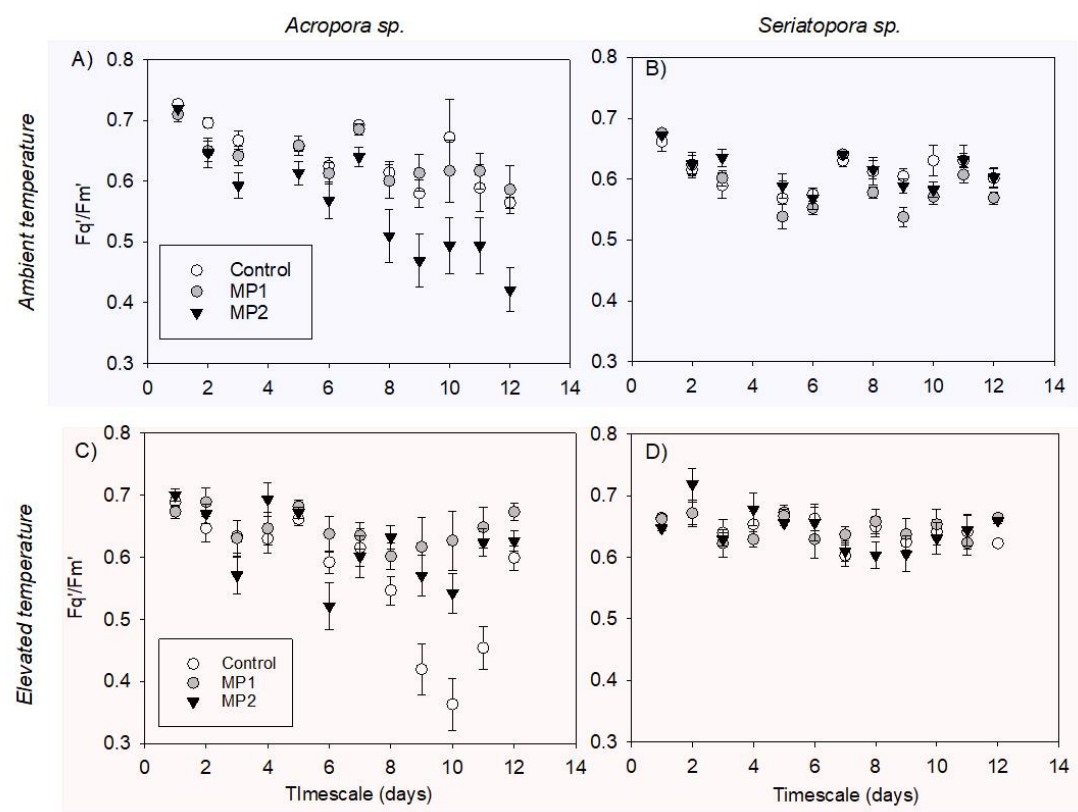
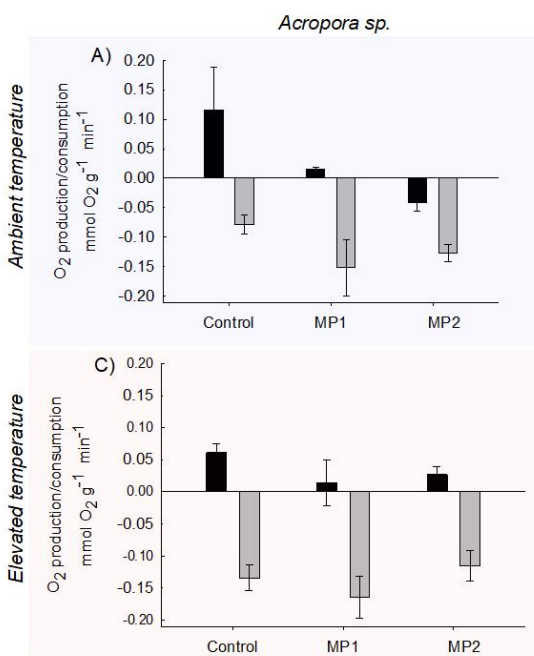
corals exposed to microplastic fibres.
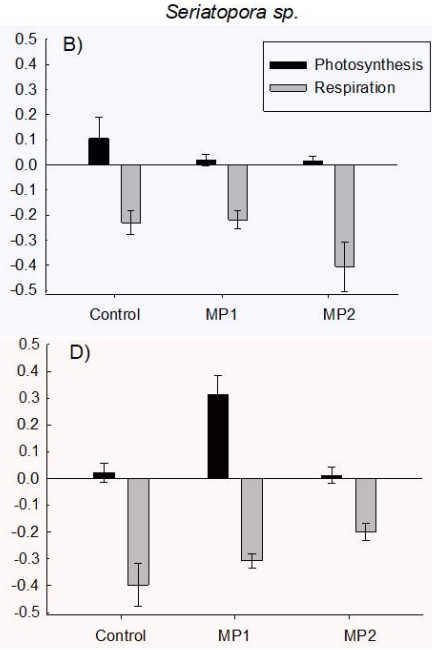

Figure 1: The changes in average $\mathrm{F}_{\mathrm{q}} / \mathrm{F}_{\mathrm{m}}{ }^{\prime}$ over the 12 day period for Acropora sp. and Seriatorpora sp. at A-B) ambient temperature $\left(26^{\circ} \mathrm{C}\right)$ and C-D) elevated temperature (26 -

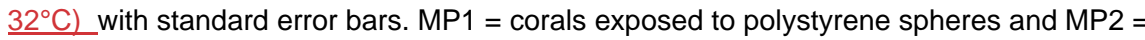

Figure 2: The average gross photosynthesis $\left(\mathrm{O}_{2}\right.$ production) and net respiration $\mathrm{CO}_{2}$ 


\author{
Seriatopora sp. at A-B) ambient temperature $\left(26^{\circ} \mathrm{C}\right)$ and C-D) elevated temperature (26 -

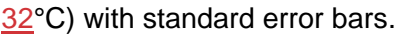 \\ MP1 \\ $=$ corals exposed to polystyrene spheres and MP2 $=$ corals exposed to microplastic fibres.
}

\title{
Funding
}

FM received funding from the Energy and Environment Institute, University of Hull, funded PhD scholarship. SH received funding from NERC (NE/K009028/1 and NE/K009028/2).

\section{CRediT author statement}

Freija M. Mendrik: Conceptualization, Methodology, Validation, Formal analysis, Investigation, Writing - Original Draft, Writing - Review \& Editing, Visualization, Project administration Heidi Burdett: Validation, Writing - Review \& Editing Theodore B. Henry: Validation, Resources, Writing - Review \& Editing Christopher Hackney: Validation, Writing - Review \& Editing, Supervision Catherine Waller: Validation, Writing - Review \& Editing, Supervision Daniel R. Parsons: Validation, Writing - Review \& Editing, Supervision Sebastian Hennige: Conceptualization, Methodology, Writing - Review \& Editing, Visualization, Supervision, Project administration

\section{Acknowledgements}

We would like to thank Laura La Beur, Dan MacRae and Fiona Murray for assistance and support in the laboratory throughout this project and Dr. James Gilbert for his advice on statistical analysis.

\section{References}

Ainsworth, T., Hoegh-Guldberg, O., 2009. Bacterial communities closely associated with coral tissues vary under experimental and natural reef conditions and thermal stress. Aquat. Biol. 4, 289-296. doi:10.3354/ab00102

Al-Sid-Cheikh, M., Rowland, S.J., Stevenson, K., Rouleau, C., Henry, T.B., Thompson, R.C., 2018. Uptake, Whole-Body Distribution, and Depuration of Nanoplastics by the Scallop Pecten maximus at Environmentally Realistic Concentrations. Environ. Sci. Technol. 52, 14480-14486. doi:10.1021/acs.est.8b05266

Allen, A.S., Seymour, A.C., Rittschof, D., 2017. Chemoreception drives plastic consumption in a hard coral. Mar. Pollut. Bull. 124, 198-205. doi:10.1016/j.marpolbul.2017.07.030

Anderson, M., 2014. The effects of temperature on gene expression in the IndoPacific reef-building coral Seriatopora hystrix: insight from aquarium studies in Southern Taiwan. Int. J. Mar. Sci. doi:10.5376/ijms.2014.04.0050

Anthony, K.R.N., 1999. Coral suspension feeding on fine particulate matter. J. Exp. 
Mar. Bio. Ecol. 232, 85-106. doi:10.1016/S0022-0981(98)00099-9

Arossa, S., Martin, C., Rossbach, S., Duarte, C.M., 2019. Microplastic removal by Red Sea giant clam (Tridacna maxima). Environ. Pollut. 252, 1257-1266. doi:10.1016/j.envpol.2019.05.149

Avio, C.G., Gorbi, S., Lilan, M., Benedetti, M., Fattorini, D., D’Errico, G., Pauletto, M., Bargelloni, L., Regoli, F., 2015. Pollutants bioavailability and toxicological risk from microplastics to marine mussels. Environ. Pollut. 198, 211-222. doi:10.1016/j.envpol.2014.12.021

Avio, C.G., Gorbi, S., Regoli, F., 2017. Plastics and microplastics in the oceans: From emerging pollutants to emerged threat. Mar. Environ. Res. 128, 2-11. doi:10.1016/j.marenvres.2016.05.012

Barnes, D.K.A., Galgani, F., Thompson, R.C., Barlaz, M., 2009. Accumulation and fragmentation of plastic debris in global environments. Philos. Trans. R. Soc. Lond. B. Biol. Sci. 364, 1985-98. doi:10.1098/rstb.2008.0205

Bhattacharya, P., Lin, S., Turner, J.P., Ke, P.C., 2010. Physical adsorption of charged plastic nanoparticles affects algal photosynthesis. J. Phys. Chem. C 114, 16556-16561. doi:10.1021/jp1054759

Biscéré, T., Lorrain, A., Rodolfo-Metalpa, R., Gilbert, A., Wright, A., Devissi, C. Peignon, C., Farman, R., Duvieilbourg, E., Payri, C., Houlbrèque, F., 2017. Nickel and ocean warming affect scleractinian coral growth. Mar. Pollut. Bull. 120, 250-258. doi:10.1016/j.marpolbul.2017.05.025

Brack, W., Frank, H., 1998. Chlorophyll a fluorescence: a tool for the investigation of toxic effects in the photosynthetic apparatus. Ecotoxicol. Environ. Saf. 40, 3441. doi:10.1006/eesa.1997.1639

Browne, M.A., Crump, P., Niven, S.J., Teuten, E., Tonkin, A., Galloway, T., Thompson, R., 2011. Accumulation of Microplastic on Shorelines Woldwide: Sources and Sinks. Environ. Sci. Technol. 45, 9175-9179. doi:10.1021/es201811s

Browne, M.A., Dissanayake, A., Galloway, T.S., Lowe, D.M., Thompson, R.C., 2008. Ingested Microscopic Plastic Translocates to the Circulatory System of the Mussel, Mytilus edulis (L.). Environ. Sci. Technol. 42, 5026-5031. doi:10.1021/es800249a

Browne, M.A., Galloway, T.S., Thompson, R.C., 2010. Spatial Patterns of Plastic Debris along Estuarine Shorelines. Environ. Sci. Technol. 44, 3404-3409. doi:10.1021/es903784e

Chae, Y., An, Y.J., 2017. Effects of micro- and nanoplastics on aquatic ecosystems: Current research trends and perspectives. Mar. Pollut. Bull. 124, 624-632. doi:10.1016/j.marpolbul.2017.01.070

Chapron, L., Peru, E., Engler, A., Ghiglione, J.F., Meistertzheim, A.L., Pruski, A.M., Purser, A., Vétion, G., Galand, P.E., Lartaud, F., 2018. Macro- and microplastics affect cold-water corals growth, feeding and behaviour. Sci. Rep. 8, 15299. doi:10.1038/s41598-018-33683-6

Chen, Q., Gundlach, M., Yang, S., Jiang, J., Velki, M., Yin, D., Hollert, H., 2017. Quantitative investigation of the mechanisms of microplastics and nanoplastics toward zebrafish larvae locomotor activity. Sci. Total Environ. 584-585, 10221031. doi:10.1016/j.scitotenv.2017.01.156

Cincinelli, A., Scopetani, C., Chelazzi, D., Lombardini, E., Martellini, T., Katsoyiannis, A., Fossi, M.C., Corsolini, S., 2017. Microplastic in the surface waters of the Ross Sea (Antarctica): Occurrence, distribution and characterization by FTIR. Chemosphere 175, 391-400. doi:10.1016/j.chemosphere.2017.02.024 
Claessens, M., Meester, S. De, Landuyt, L. Van, Clerck, K. De, Janssen, C.R., 2011. Occurrence and distribution of microplastics in marine sediments along the Belgian coast. Mar. Pollut. Bull. 62, 2199-2204. doi:10.1016/j.marpolbul.2011.06.030

Coles, S.L., Brown, B.E., 2003. Coral bleaching--capacity for acclimatization and adaptation. Adv. Mar. Biol. 46, 183-223. doi:10.1016/S0065-2881(03)46004-5

Davies, S.W., Ries, J.B., Marchetti, A., Castillo, K.D., 2018. Symbiodinium functional diversity in the Coral Siderastrea siderea Is influenced by thermal stress and reef environment, but not ocean acidification. Front. Mar. Sci. 5, 1-14. doi:10.3389/fmars.2018.00150

Derraik, J.G.., 2002. The pollution of the marine environment by plastic debris: A review. Mar. Pollut. Bull. doi:10.1016/S0025-326X(02)00220-5

Ding, J., Jiang, F., Li, J., Wang, Zongxing, Sun, C., Wang, Zhangyi, Fu, L., Ding, N.X., He, C., 2019. Microplastics in the Coral Reef Systems from Xisha Islands of South China Sea. Environ. Sci. Technol. 53, 8036-8046. doi:10.1021/acs.est.9b01452

Dubinsky, Z., Stambler, N., 1996. Marine pollution and coral reefs. Glob. Chang. Biol. 2, 511-526. doi:10.1111/j.1365-2486.1996.tb00064.x

Edmunds, P.J., 2005. Effect of elevated temperature on aerobic respiration of coral recruits. Mar. Biol. 146, 655-663. doi:10.1007/s00227-004-1485-5

Elahifard, E., Ghanbari, A., Hasan, M., Mohassel, R., Zand, E., Mirshamsi, A., Abbaspoor, M., 2013. Measuring chlorophyll fluorescence parameters for rapid detection of ametryn resistant. Plant Knowl. J. 2, 76-82.

Fine, M., Loya, Y., 2002. Endolithic algae: an alternative source of photoassimilates during coral bleaching. Proc. R. Soc. London. Ser. B Biol. Sci. 269, 1205-1210. doi:10.1098/rspb.2002.1983

Fossi, M.C., Panti, C., Guerranti, C., Coppola, D., Giannetti, M., Marsili, L., Minutoli, R., 2012. Are baleen whales exposed to the threat of microplastics? A case study of the Mediterranean fin whale (Balaenoptera physalus). Mar. Pollut. Bull. 64, 2374-2379. doi:10.1016/j.marpolbul.2012.08.013

Franqueira, D., Orosa, M., Torres, E., Herrero, C., Cid, A., 2000. Potential use of flow cytometry in toxicity studies with microalgae. Sci. Total Environ. 247, 119126. doi:10.1016/S0048-9697(99)00483-0

Garnier, Y., Jacob, H., Guerra, A.S., Bertucci, F., Lecchini, D., 2019. Evaluation of microplastic ingestion by tropical fish from Moorea Island, French Polynesia. Mar. Pollut. Bull. 140, 165-170. doi:10.1016/J.MARPOLBUL.2019.01.038

Genty, B., Briantais, J., Baker, N., 1989. The relationship between the quantum yield of photosynthetic electron transport and quenching of chlorophyll fluorescence. Biochim. Biophys. Acta - Gen. Subj. 990, 87-92.

Goldberg, W.M., 2002. Gastrodermal structure and feeding responses in the scleractinian Mycetophyllia reesi, a coral with novel digestive filaments. Tissue Cell 34, 246-261. doi:10.1016/S0040-8166(02)00008-3

Greer, L., Jackson, J.E., Curran, H.A., Guilderson, T., Teneva, L., 2009. How vulnerable is Acropora cervicornis to environmental change? Lessons from the early to middle Holocene. Geology 37, 263-266. doi:10.1130/G25479A.1

Grottoli, A.G., Rodrigues, L.J., Palardy, J.E., 2006. Heterotrophic plasticity and resilience in bleached corals. Nature 440, 1186-1189.

Halden, R.U., 2010. Plastics and health risks. Annu. Rev. Public Health 31, 179-94. doi:10.1146/annurev.publhealth.012809.103714

Hall, N.M., Berry, K.L.E., Rintoul, L., Hoogenboom, M.O., 2015. Microplastic 
ingestion by scleractinian corals. Mar. Biol. 162, 725-732. doi:10.1007/s00227015-2619-7

Hamilton, R.J., Almany, G.R., Brown, C.J., Pita, J., Peterson, N.A., Howard Choat, J., 2017. Logging degrades nursery habitat for an iconic coral reef fish. Biol. Conserv. 210, 273-280. doi:10.1016/j.biocon.2017.04.024

Hankins, C., Duffy, A., Drisco, K., 2018. Scleractinian coral microplastic ingestion: Potential calcification effects, size limits, and retention. Mar. Pollut. Bull. 135, 587-593. doi:10.1016/J.MARPOLBUL.2018.07.067

Hennige, S.J., Smith, D.J., Perkins, R., Consalvey, M., Paterson, D.M., Suggett, D.J., 2008. Photoacclimation, growth and distribution of massive coral species in clear and turbid waters. Mar. Ecol. Prog. Ser. 369, 77-88. doi:10.3354/meps07612

Hofmann, G.E., Todgham, A.E., 2010. Living in the Now: Physiological Mechanisms to Tolerate a Rapidly Changing Environment. Annu. Rev. Physiol. 72, 127-145. doi:10.1146/annurev-physiol-021909-135900

Huang, Y., Yan, M., Xu, K., Nie, H., Gong, H., Wang, J., 2019. Distribution characteristics of microplastics in Zhubi Reef from South China Sea. Environ. Pollut. doi:10.1016/j.envpol.2019.113133

Hughes, T.P., Barnes, M.L., Bellwood, D.R., Cinner, J.E., Cumming, G.S., Jackson, J.B.C., Kleypas, J., Van De Leemput, I.A., Lough, J.M., Morrison, T.H., Palumbi, S.R., Van Nes, E.H., Scheffer, M., 2017. Coral reefs in the Anthropocene. Nature 546, 82-90. doi:10.1038/nature22901

Jones, R.J., Hoegh-Guldberg, O., 2001. Diurnal changes in the photochemical efficiency of the symbiotic dinoflagellates (Dinophyceae) of corals:

Photoprotection, photoinactivation and the relationship to coral bleaching. Plant, Cell Environ. 24, 89-99. doi:10.1046/j.1365-3040.2001.00648.x

Jones, R.J., Hoegh-Guldberg, O., Larkum, A.W.D., Schreiber, U., 1998. Temperature-induced bleaching of corals begins with impairment of the $\mathrm{CO} 2$ fixation mechanism in zooxanthellae. Plant, Cell Environ. 21, 1219-1230. doi:10.1046/j.1365-3040.1998.00345.x

Jones, R.J., Ward, S., Amri, A.Y., Hoegh-Guldberg, O., 2000. Changes in quantum efficiency of Photosystem II of symbiotic dinoflagellates of corals after heat stress, and of bleached corals sampled after the 1998 Great Barrier Reef mass bleaching event. Mar. Freshw. Res. 51, 63-71. doi:10.1071/MF99100

Krause, G.H., Weis, E., 1991. Chlorophyll Fluorescence and Photosynthesis: The Basics. Annu. Rev. Plant Physiol. Plant Mol. Biol. 42, 313-349. doi:10.1146/annurev.pp.42.060191.001525

LaJeunesse, T.C., Parkinson, J.E., Gabrielson, P.W., Jeong, H.J., Reimer, J.D., Voolstra, C.R., Santos, S.R., 2018. Systematic Revision of Symbiodiniaceae Highlights the Antiquity and Diversity of Coral Endosymbionts. Curr. Biol. 28, 2570-2580.e6. doi:10.1016/J.CUB.2018.07.008

Leggat, W., Seneca, F., Wasmund, K., Ukani, L., Yellowlees, D., Ainsworth, T.D., 2011. Differential Responses of the Coral Host and Their Algal Symbiont to Thermal Stress. PLoS One 6, e26687. doi:10.1371/journal.pone.0026687 Lenz, R., Enders, K., Nielsen, T.G., 2016. Microplastic exposure studies should be environmentally realistic. Proc. Natl. Acad. Sci. U. S. A. 113, E4121-E4122. doi:10.1073/pnas.1606615113

Lesser, M.P., 1997. Oxidative stress causes coral bleaching during exposure to elevated temperatures. Coral Reef 16, 187-192.

Levy, O., Achituv, Y., Yacobi, Y.Z., Dubinsky, Z., Stambler, N., 2006. Diel tuning of 
coral metabolism: physiological responses to light cues. J. Exp. Biol. 209, 273283.

Livingstone, D.R., 2003. Oxidative stress in aquatic organisms in relation to pollution and aquaculture. Rev. Med. Vet. (Toulouse). 427-430.

Lusher, A.L., McHugh, M., Thompson, R.C., 2013. Occurrence of microplastics in the gastrointestinal tract of pelagic and demersal fish from the English Channel. Mar. Pollut. Bull. 67, 94-99. doi:10.1016/J.MARPOLBUL.2012.11.028

Mass, T., Einbinder, S., Brokovich, E., Shashar, N., Vago, R., Erez, J., Dubinsky, Z., 2007. Photoacclimation of Stylophora pistillata to light extremes: Metabolism and calcification. Mar. Ecol. Prog. Ser. 334, 93-102. doi:10.3354/meps334093

Meeker, J.D., Sathyanarayana, S., Swan, S.H., 2009. Phthalates and other additives in plastics: human exposure and associated health outcomes. Philos. Trans. R. Soc. Lond. B. Biol. Sci. 364, 2097-113. doi:10.1098/rstb.2008.0268

Mills, M.M., Lipschultz, F., Sebens, K.P., 2004. Particulate matter ingestion and associated nitrogen uptake by four species of scleractinian corals. Coral Reefs 23, 311-323. doi:10.1007/s00338-004-0380-3

Mouchi, V., Chapron, L., Peru, E., Pruski, A.M., Meistertzheim, A.-L., Vétion, G., Galand, P.E., Lartaud, F., 2019. Long-term aquaria study suggests speciesspecific responses of two cold-water corals to macro-and microplastics exposure. Environ. Pollut. 253, 322-329. doi:10.1016/J.ENVPOL.2019.07.024

Munari, C., Infantini, V., Scoponi, M., Rastelli, E., Corinaldesi, C., Mistri, M., 2017. Microplastics in the sediments of Terra Nova Bay (Ross Sea, Antarctica). Mar. Pollut. Bull. 122, 161-165. doi:10.1016/j.marpolbul.2017.06.039

Murray, F., Cowie, P.R., 2011. Plastic contamination in the decapod crustacean Nephrops norvegicus (Linnaeus, 1758). Mar. Pollut. Bull. 62, 1207-1217. doi:10.1016/J.MARPOLBUL.2011.03.032

Nie, H., Wang, J., Xu, K., Huang, Y., Yan, M., 2019. Microplastic pollution in water and fish samples around Nanxun Reef in Nansha Islands, South China Sea. Sci. Total Environ. 696, 134022. doi:10.1016/J.SCITOTENV.2019.134022

Nii, C.M., Muscatine, L., 1997. Oxidative stress in the symbiotic sea anemone Aiptasia pulchella (Carlgren, 1943): Contribution of the animal to superoxide ion production at elevated temperature. Biol. Bull. 192, 444-456. doi:10.2307/1542753

Oehlmann, J., Oetken, M., Schulte-Oehlmann, U., 2008. A critical evaluation of the environmental risk assessment for plasticizers in the freshwater environment in Europe, with special emphasis on bisphenol A and endocrine disruption. Environ. Res. 108, 140-149. doi:10.1016/j.envres.2008.07.016

Okubo, N., Takahashi, S., Nakano, Y., 2018. Microplastics disturb the anthozoanalgae symbiotic relationship. Mar. Pollut. Bull. 135, 83-89. doi:10.1016/j.marpolbul.2018.07.016

Owen, R., Knap, A., Ostrander, N., Carbery, K., 2003. Comparative Acute Toxicity of Herbicides to Photosynthesis of Coral Zooxanthellae Environmental Contamination and Toxicology 541. Environ. Contam. Toxicol 70, 541-548. doi:10.1007/s00128-003-0020-6

Paul-Pont, I., Lacroix, C., González Fernández, C., Hégaret, H., Lambert, C., Le Goïc, N., Frère, L., Cassone, A.L., Sussarellu, R., Fabioux, C., Guyomarch, J., Albentosa, M., Huvet, A., Soudant, P., 2016. Exposure of marine mussels Mytilus spp. to polystyrene microplastics: Toxicity and influence on fluoranthene bioaccumulation. Environ. Pollut. 216, 724-737. doi:10.1016/j.envpol.2016.06.039 
PlasticsEurope (Association of Plastics Manufacturers), 2018. An analysis of European plastics production, demand and waste data. Plast. - facts 2018 1-57.

Provencher, J.F., Bond, A.L., Mallory, M.L., 2014. Marine birds and plastic debris in Canada: a national synthesis and a way forward. Environ. Rev. 23, 1-13. doi:10.1139/er-2014-0039

$\mathrm{R}$ Core Team, 2013. R: A language and environment for statistical computing. $R$ Found. Stat. Comput. Vienna, Austria.

Ralph, P.J., Gademann, R., Larkum, A.W.D., 2001. Zooxanthellae expelled from bleached corals at $33^{\circ} \mathrm{C}$ are photosynthetically competent. Mar. Ecol. Prog. Ser. 220, 163-168. doi:10.3354/meps220163

Reichert, J., Arnold, A.L., Hoogenboom, M.O., Schubert, P., Wilke, T., 2019. Impacts of microplastics on growth and health of hermatypic corals are species-specific. Environ. Pollut. 254, 113074. doi:10.1016/J.ENVPOL.2019.113074

Reichert, J., Schellenberg, J., Schubert, P., Wilke, T., 2018. Responses of reef building corals to microplastic exposure. Environ. Pollut. 237, 955-960. doi:10.1016/j.envpol.2017.11.006

Reshef, L., Koren, O., Loya, Y., Zilber-Rosenberg, I., Rosenberg, E., 2006. The Coral Probiotic Hypothesis. Environ. Microbiol. 8, 2068-2073. doi:10.1111/j.1462-2920.2006.01148.x

Richmond, R.H., 1993. Coral reefs: preent problems and future concerns resulting from anthropogenic disturbance. Am. Zool. 33, 524-536. doi:10.1093/icb/33.6.524

Ryan, P.G., Moore, C.J., van Franeker, J.A., Moloney, C.L., 2009. Monitoring the abundance of plastic debris in the marine environment. Philos. Trans. R. Soc. B Biol. Sci. 364, 1999-2012. doi:10.1098/rstb.2008.0207

Saliu, F., Montano, S., Garavaglia, M.G., Lasagni, M., Seveso, D., Galli, P., 2018. Microplastic and charred microplastic in the Faafu Atoll, Maldives. Mar. Pollut. Bull. 136, 464-471. doi:10.1016/J.MARPOLBUL.2018.09.023

Schreiber, U., 2004. Pulse-Amplitude-Modulation (PAM) Fluorometry and Saturation Pulse Method: An Overview, in: Chlorophyll a Fluorescence. Springer Netherlands, Dordrecht, pp. 279-319. doi:10.1007/978-1-4020-3218-9_11

Schreiber, U., Neubauer, C., Schliwa, U., 1993. PAM fluorometer based on mediumfrequency pulsed Xe-flash measuring light: A highly sensitive new tool in basic and applied photosynthesis research. Photosynth. Res. 36, 65-72. doi:10.1007/BF00018076

Setälä, O., Fleming-Lehtinen, V., Lehtiniemi, M., 2014. Ingestion and transfer of microplastics in the planktonic food web. Environ. Pollut. 185, 77-83. doi:10.1016/j.envpol.2013.10.013

Sussarellu, R., Suquet, M., Thomas, Y., Lambert, C., Fabioux, C., Pernet, M.E.J., Le Goïc, N., Quillien, V., Mingant, C., Epelboin, Y., Corporeau, C., Guyomarch, J., Robbens, J., Paul-Pont, I., Soudant, P., Huvet, A., 2016. Oyster reproduction is affected by exposure to polystyrene microplastics. Proc. Natl. Acad. Sci. U. S. A. 113, 2430-5. doi:10.1073/pnas.1519019113

Takahashi, S., Murata, N., 2008. How do environmental stresses accelerate photoinhibition? Trends Plant Sci. 13, 178-182. doi:10.1016/j.tplants.2008.01.005

Talsness, C., 2009. Components of plastic: experimental studies in animals and relevance for human health. Philos. Trans. R. Soc. B Biol. Sci. 364, 2079-2096.

Tang, J., Ni, X., Zhou, Z., Wang, L., Lin, S., 2018. Acute microplastic exposure raises stress response and suppresses detoxification and immune capacities in 
the scleractinian coral Pocillopora damicornis. Environ. Pollut. 243, 66-74. doi:10.1016/J.ENVPOL.2018.08.045

Thompson, R.C., Olsen, Y., Mitchell, R.P., Davis, A., Rowland, S.J., John, A.W.G., McGonigle, D., Russell, A.E., 2004. Lost at sea: where is all the plastic? Science 304, 838. doi: $10.1126 /$ science. 1094559

Walker, T.R., 2018. Drowning in debris: Solutions for a global pervasive marine pollution problem. Mar. Pollut. Bull. doi:10.1016/j.marpolbul.2017.11.039

Warner, M.E., Fitt, W.K., Schmidt, G.W., 1996. The effects of elevated temperature on the photosynthetic efficiency of zooxanthellae in hospite from four different species of reef coral: A novel approach. Plant, Cell Environ. 19, 291-299. doi:10.1111/j.1365-3040.1996.tb00251.x

Weis, V.M., 2010. The susceptibility and resilience of corals to thermal stress: Adaptation, acclimatization or both?: NEWS and VIEWS. Mol. Ecol. 19, 15151517. doi:10.1111/j.1365-294X.2010.04575.x

Wild, C., Huettel, M., Klueter, A., Kremb, S.G., Rasheed, M.Y.M., Jørgensen, B.B., 2004. Coral mucus functions as an energy carrier and particle trap in the reef ecosystem. Nature 428, 66-70. doi:10.1038/nature02344

Wright, S., Galloway, Tamara Susan, Wright, S.L., Thompson, R.C., Galloway, Tamara S, 2013. The physical impacts of microplastics on marine organisms: A review Investigating microplastic contamination in coastal waters View project Tracking relevant nanomaterial transformations, exposure, uptake and effects in freshwater and soil systems View pr. Artic. Environ. Pollut. doi:10.1016/j.envpol.2013.02 